Ann. Biol. anim. Bioch. Biophys., I976, 16 (3), 409-412.

\title{
PARTIAL PURIFFCATION \\ OF DIFFERENT PITUITARY CELL TYPES IN THE RAT : A STUDY ON DEVELOPMENTAL CHANGES IN CELL TYPE DISTRIBUTION AND CORRELATION WITH IN SITU CONVERSION OF TESTOSTERONE TO $5 \alpha$-DIHYDROTESTOSTERONE
}

\author{
C. DENEF \\ with the technical assistance of R. De Wars and A. De WorF \\ Faculteit der Geneeskunde, Afdeling Farmacologie, \\ Katholieke Universiteit te Leuven, \\ 3000 Leuven (Belgium)
}

Two major aspects can be recognized in the study of pituitary gonadotropin secretion : one concerns the regulatory mechanisms in hormone synthesis and secretion, the other involves the differentiation of the specific cell type or cell types which produce the two gonadotropic hormones, FSH and LH. It is well known that synthesis and secretion are regulated by the hypothalamic $\mathrm{LH} / \mathrm{FSH}$ releasing hormone ( $\mathrm{LH} / \mathrm{FSH}-\mathrm{RH})$ and by steroid feedback from the gonads. On the other hand little is known about the differentiation of the gonadotroph and it is still debated whether or not LH and FSH are produced in the same or in different cell types. Since the action of regulating hormones on the gonadotroph is related to its differentiated state, one has to look for biochemical parameters of hormone action which would correlate with functional and morphological characteristics of the gonadotroph. Such parameters of hormone action may be the in situ conversion of testosterone to $5 \alpha$-dihydrotestosterone, an active metabolite of the androgen, binding of the steroid hormone to presumptive intracellular receptors and interaction of the LH/FSH-RH with the plasma membrane.

One important approach in this respect is to look at the pituitary during development since it is then that the most striking fluctuation in FSH and $\mathrm{L}, \mathrm{H}$ levels as well as in FSH:L $\mathrm{H}$ ratio occur in the rat.

We have previously studied the in vitro conversion of testosterone to $\vec{j} \alpha$-dihydrotestosterone (DHT) in the intact anterior pituitary of the rat and have found that its formation rate fluctuated tremendeously with age and sex (DENEF et al., I974). The most striking changes were a peak of activity in the female at $I_{5}$ days of age and in the male around 30 days of age. The rate of conversion was also severalfold 
increased after gonadectomy and this could be prevented by testosterone administration. The magnitude of these changes was also different according to age and sex. When these fluctuations in pituitary DHT formation were compared with pituitary gonadotropin secretion in similar circumstances, a striking correlation was found with FSH secretion and/or FSH:LH ratio. High conversion rates of DHT were always associated with high FSH levels and/or high FSH:LH ratios. The hypothesis was presented that DHT formation reflects the functional state of a particular pituitary cell type, presumably a gonadotroph and the question was raised whether the phenomenon was due to the differentiation of a specific FSH cell type or to an adaptive change of a common cell type which secretes both FSH and $\mathrm{L}_{\mathbf{H}} \mathrm{H}$.

A major obstacle to investigate this problem further is the cellular heterogeneity of the pituitary. Recently, however, a new technique has been introduced by which enriched populations of certain cell types could be obtained (HYMER et al., I973 ; LLOYD and McShaN, I973). This technique consists of sedimenting cells on albumin gradients at unit gravity which allows some separation of cell types mainly according to size.

We have adopted this technique to study changes in cell distribution during development, and to corellate the rate of DHT formation, measured in the different cell fractions obtained, with the abundance of a particular cell type in the enriched fraction.

Monodispersed pituitary cells from Wistar rats were prepared by the method described by HOPKINS and FARQUHAR (I973). Enrichment of cell types was obtained by sedimentation at unit gravity through a $0.3-2.4 \mathrm{p}$. Ioo bovine serum albumin gradient of $500 \mathrm{ml}$ made up in Eagle's Minimum Essential Medium. The gradient was eluted in Io to I I fractions of $50 \mathrm{ml}$ starting at the top and the cells were collected by centrifugation. The different cell types were identified by differential staining with the Herlant Permanganate-Alcian blue-PAS-Orange G method. Cells resuspended in $5^{\circ} \mu \mathrm{l}$ of Eagle's Medium, were incubated with $\mathrm{H}^{3}$-testosterone at $10^{-8} \mathrm{M}$ during 4 hours at $37^{\circ} \mathrm{C}$ under $\mathrm{O}_{2} / \mathrm{CO}_{2}$ 95/5. Metabolites and remaining substrate were extracted in ethanol, chromatographed on TLC plates and counted for radioactivity. Conversion of testosterone to $\mathrm{DH}^{\prime} \mathrm{T}$ was expressed per roo $\mu \mathrm{g}$ protein.

The following results were obtained :

\section{Adult male rats.}

PAS-purple gonadotrophs were most concentrated in fraction 8 ( 30 p. Ioo), PAS-red gonadotrophs in fraction $6(\sim 20$ p. Ioo, somatotrophs in Fraction II ( $\sim 75 \mathrm{p}$. IOO) and chromophobes in fraction 4 (up to $90 \mathrm{p}$. IOo). Conversion of testosterone to DHT was several times higher in fractions with an enriched population of PAS-purple gonadotrophs than in the fractions containing a predominant population of somatotrophs or chromophobes. Other metabolites were formed in much lower amouts than DHT.

\section{Female rats 15 days old.}

The distribution of cell types was very different from that in adult life. The somatotrophs but not the gonadotrophs were much smaller than in adult life. A highly enriched fraction of PAS-purple gonadotrophs was obtained in fraction 
II $(\sim 70$ p. Ioo). PAS-red cells were scarce and not particularly concentrated in any fraction. A peak of somatotrophs was found in fraction $6\left(\sim 3^{8}\right.$ p. Ioo) and of chromophobes in fraction $4(\sim 90 \mathrm{p}$. IOo). When DHT formation was tested in these fractions, again the rate of conversion increased with increasing percentage of PAS-purple gonadotrophs in the population. The specific activity of the conversion was also 20-30 times higher than in adult life.

\section{Male rats 30 days old.}

Again a different profile was obtained. PAS-purple gonadotrophs concentrated in fraction Io and II but only up to about 50 p. IOO, a peak of somatotrophs was found in fraction $8\left(\sim 5^{\circ} \mathrm{p}\right.$. Ioo) and of PAS-red cells in fraction 7 ( $\sim$ I2 p. IOo). Conversion rates to DHT again increased with the number of PAS-purple gonadotrophs in the population and was also several times higher than in adult life.

It is concluded that by careful selection of the age and sex of the animal, considerably enriched populations of pituitary cell types can be obtained, and of a similar cell type, enriched populations with different morphological characteristics as based on cell size can be obtained. One functional correlate of hormone action, the conversion of testosterone to DHT, seems to be associated with PAS-purple gonadotrophs. Highly enriched populations of these gonadotrophs can be prepared which show different intrinsic activity in this conversion rate and may therefore consist of gonadotrophs in different functional states with respect to their FSH synthesis or secretion. Work is in progress to further characterize these cells by immunocytochemical demonstration of the type of gonadotropin they contain and in their ability to bind and to respond to $\mathrm{I}, \mathrm{H} / \mathrm{FSH}-\mathrm{RH}$.

Sexual Maturation, 3rd Workshop. August 31, September 3, 1975.

\section{ACKNOWLEDGEMENTS}

This research was sustained by grants from the "National Fonds voor Wetenschappelijk Onderzoek ", the "Fonds voor Geneeskundig Wetenschappelijk Onderzoek " and by a University grant "Fonds II Ide Cyclus".

\section{RÉSUMÉ}

PURIFICATION PARTIELLLE DES DIFFÉRENTS TYPES

DE CELLULES HYPOPHYSAIRES CHEZ LE RAT :

ÉTUDE DES CHANGEMENTS DANS LA DISTRIBUTION DES TYPES CELLULAIRES

AU COURS DU DÉVELOPPEMENT ET CORRÉLATION AVEC LA CONVERSION IN SITU DE IA TESTOSTÉRONE EN $5 \alpha$-DIHYDROTESTOSTÉRONE

La préparation de fractions enrichies des divers types de cellules hypophysaires par la méthode cle sédimentation différentielle identifiées par coloration différentielle chez des rats adultes et immatures et l'étude de la conversion de la testostérone en DHT dans ces différentes fractions, a montré que : 
I) les cellules somatotropes sont beaucoup plus grandes chez l'animal adulte ;

2) c'est toujours dans la fraction enrichie en cellules gonadotropes PAS-pourpres que la conversion de la testostérone en DHT est la plus élevée.

Les populations enrichies en cellules gonadotropes PAS-pourpres montrent des activités variables du taux de conversion de la testostérone, qu'on pourra peut-être mettre en relation avec des stades de fonctionnement différents pour la synthèse ou la sécrétion de FSH.

\section{REFERENCES}

Denef C., Magnus C., McEwen B. S., 1974. Sex dependent changes in pituitary $5 \alpha$-dihydrotestosterone and $3 \alpha$-androstandiol formation during postnatal development and puberty in the rat. Endocrinology, 94, 1265-1274.

Hopkins C. R., Farouhar M. G., 1973. Hormone secretion by cells dissociated from rat anterior pituitaries. J. Cell Biol., 59, 276-303.

Hymer W. C., Evans W. H., Kraicer J., Mastro A., Davis J., Griswold E., I973. Entichment of cell type from rat adenohypophysis by sedimentation at unit gravity. Endocrinology, 92, 275287.

Lloyd R. V., McShan W. H., 1973. Study of rat anterior pituitary cells separated by velocity sedimentation at unit gravity. Endocrinology, 92, I639-1651. 